\title{
Implementing a Certificate of Information Literacy programme and engaging with faculty: a case study of the Cape Peninsula University of Technology
}

\author{
Zulaiga Davids ${ }^{1}$ and Yunus Omar ${ }^{2}$ \\ davidsz@cput.ac.za ORCID: orcid.org/0000-0003-3625-6334 \\ omary@cput.ac.za ORCID orcid.org/0000-0003-2701-1781
}

Received: 13 September 2017

Accepted: 15 May 2018

The purpose of this study was to evaluate the effectiveness of a certificate-based information literacy (IL) programme at the Cape Peninsula University of Technology. The evaluation determined whether there was improvement in the academic performance of students. It also evaluated the collaboration between the library and lecturers, and how librarians and lecturers evaluated the programme. The study used a case study approach. A questionnaire survey asked lecturers to evaluate the implementation of the programme and its impact on students' performance. In a focus group discussion, librarians reported on the students' performance and on how they engaged and collaborated with lecturers. The study was limited to two faculties and to first-year and Extended Curricular Programme (ECP) or foundation level students within Communication and English classes. The results indicated effective programme implementation by using a student-centered teaching approach. The IL content was aligned to academic tasks. Formative assessments showed that student learning took place constantly. The summative assessment indicated improved student performance. Findings were validated by lecturers' feedback. The IL programme was a participatory model, resulting in a shared understanding of IL and built strong collaboration between lecturers and librarians. The implications of the study showed that the programme, the first short course offered by the library officially endorsed by the university, had been successful in its implementation, collaboration and student performance and that it offered value. It is hoped that information literacy will be fully embedded into curricula as stated by the institutional information literacy policy and for it to be part of a fully accredited course.

Keywords: Information literacy short course, academic collaboration, information literacy policy

\section{Introduction}

There are various approaches to delivering information literacy (IL) programmes in higher education. Some programmes are credit-bearing, others are non-credit-bearing. Several universities and libraries issue certificates for completion or attendance of IL programmes or compliance with IL. Certificates may be credit-bearing or not. In South Africa, the Tshwane University of Technology issues certificates for its IL programme (Tshwane University of Technology 2016), as has the Cape Peninsula University of Technology (CPUT) since 2013. In other parts of the world, twelve universities in Spain (Calderón-Rehecho, Domínguez-Aroca \& González-Fernández-Villavicencio 2013), in the USA at the Sam Houston State University (Newton Gresham Library 2010) and in Hong Kong at the Chinese University of Hong Kong (Li, Leung \& Tam 2007: 4) issue IL certificates. Programmes with IL certificates are important because they validate the levels of competencies attained. It is a recommendation by the International Federation of Library Associations and Institutions (IFLA) that libraries issue certificates of attendance on completion of IL courses. The certificates should result from some type of assessment based on standardised tests (IFLA 2015).

Certification programmes hold short and long-term benefits for students as IL is seen as "common to all disciplines, to all learning environments, and to all levels of education" (Hernández-Rabanal 2014: 328). In the short term, students will encounter different environments which will require the need to exchange and disseminate information, to conduct effective research and produce academic work such as assignments and projects. Information literacy skills will empower students to take control of their own learning and provide them with tools for lifelong learning. It would also further the

1. Zulaiga Davids is Faculty Librarian at the Cape Peninsula University of Technology, South Africa

2. Yunus Omar is Library Manager at the Cape Peninsula University of Technology, South Africa 
educational objectives of the university to enhance student learning and "to improve the retention and success rate" (Cape Peninsula University of Technology [CPUT] 2009: 2).

The long-term benefits of IL are to create lifelong learners, to equip students "with the skills to be able to succeed in a rapidly changing environment" (CPUT 2006: 5). Benefits are especially relevant as industry requires information-skilled professional staff in the work environment. A certificate would therefore hold advantages when used for temporary or permanent employment.

IL programmes are delivered either as stand-alone programmes or they are integrated or embedded into the curriculum. Statistics gathered from fourteen South African universities found that $93 \%$ of IL teaching was led by librarians, with $56 \%$ to $60 \%$ teaching $\mathrm{IL}$ as part of a course or module and $20 \%$ to $32 \%$ as a stand-alone module to firstyear students with the collaboration of lecturers (Mugwisi 2015: 30). Maitaouthong, Tuamsuk and Yupin (2012: 51) point out that "the advantages of university libraries in this respect is that the library has information sources ready for IL and has personnel with expertise in information and the ability to manage IL".

\section{Background}

CPUT's aim is to embed the IL programme into curricula as recommended by the IL policy (Lockhart 2015: 3), and for lecturers to allocate credits for the programme in the future. In 2009, the IL policy was accepted at Senate. The Information Literacy Committee (ILC) comprising of lecturers, librarians and other academic units was formed to monitor the IL policy implementation process. One of the tasks of the ILC was to audit lecturers' subject guides to check for IL integration into their curricula. The ILC found that IL was not integrated into most subjects. The IL deficiency in the subject guides led to the development of a short course called the Certificate of Information Literacy (CIL) in 2012. The CIL, spearheaded by the library, was endorsed by the Curriculum Officers' Forum (COF) for its academic value. The CIL started as a stand-alone programme linked to a specific assignment or it was integrated into a course.

Information literacy (IL) "means that students must not only be able to recognise when information is needed, but also be able to identify, locate, evaluate and use information ethically for decision-making" (American Library Association [ALA] 2000: 2). CPUT took the traditional approach to IL by using the ACRL Standards (ALA 2000) as a framework for the CIL. The CIL enables librarians and lecturers to assess students' basic IL skills across five standards and outcomes. The CIL will phase out the Standards and replace it with the new Framework for Information Literacy in Higher Education (Association of College and Research Libraries [ACRL] 2016). IL should become a key component of teaching and learning, and collaboration between lecturers and librarians is needed.

The objective was to roll out the CIL programme to one department each in the Faculty of Business (FoB) and the Faculty of Informatics and Design (FID), for first-year and Extended Curriculum Programme (ECP) students. ECP students are not yet ready for first-year university studies. ECPs provide extended support for underprepared students so that they adjust to the tertiary environment and cope with the new workload: "Students are placed on Ministerial approved extended curriculum programmes, which are in most cases one year longer than the regular qualification" (Department of Higher Education and Training [DHET] 2012). ECP and first-year students do either Communication or English as a compulsory subject. It was with the lecturers of these subjects that librarians liaised and to whom the CIL was offered. The CIL is a non-credit bearing short course that offers lecturers a choice of three formats: online self-learning, joint lecturer and librarian training, or face-to-face instruction by librarians. Both faculties chose face-to face sessions with all five modules taught by librarians followed by an assessment on the institution's online Learning Management System (LMS), Blackboard. The case study describes and presents the findings from an investigation into the delivery of the CIL programme in the two faculties and makes recommendations for future training.

\section{Research problem}

Librarians face many challenges when delivering IL programmes, especially when it comes to collaboration with lecturers. At CPUT, because of the challenges, there have been calls for new approaches to the teaching of IL to address how the IL programme implementation at CPUT can be improved through an evaluation of the existing programme approach. This paper answers the following questions:

- What approach was used to implement the CIL?

- Was the collaboration between lecturers and librarians successful in delivering IL?

- Did the CIL contribute to any improvement in students' learning?

- What were the results of the evaluation of the IL programme by lecturers and librarians? 


\section{Literature Review}

The literature review focuses on four broad areas: the implementation of the IL policy, collaboration between lecturers and librarians, student performance, and evaluation by lecturers and librarians.

\subsection{IL policy implementation}

Information literacy as a field is well researched and documented. While information literacy policy development and implementation in higher education institutions is growing, libraries still face the challenge of working collaboratively with other stakeholders who in many cases are reluctant to accept the policy. A survey conducted by the International Association of Scientific and Technological University Libraries (IATUL) among its members showed that thirty-six out of 100 member university libraries have developed their own IL policies. In other environments, IL implementation is dictated by set guidelines from government or professional associations (IATUL 2015). IFLA recognises the need for IL and has developed guidelines and IL materials that can be used (IFLA 2015) and adapted to the institutional environment.

Previous studies on IL policy development in universities have been rather limited (Idiodi 2005, Basili 2011, Anyaoku, Ezeani and Osuigwe 2015). Literature has paid more attention to practical aspects of IL. As early as 1974, Zurkowski advocated for a national IL programme, but it remained an idea only (Basili 2011: 415). Libraries were found to be the main drivers in making $\mathrm{IL}$ a credit-bearing course in their institutions and opted to advise how the learning outcomes can be achieved (Jarson 2010: 535, Virkus 2012: 33, Lockhart 2015: 3). Universities which do not have an IL policy or guidelines and have no IL programme can use stand-alone online programs such as MOSAIC and SAFARI to offer IL training (Idiodi 2005: 223, Anyaoku, Ezeani and Osuigwe 2015: 100).

In South Africa, IL is addressed at the highest levels by the National Qualification Framework (NQF) and the Committee of Higher Education Libraries of South Africa (CHELSA). The NQF lists generic outcomes for teaching and learning. These Critical Cross Field Outcomes (CCFO) which are "collecting, analysing, organising and critically evaluating information" reflect the basic teaching of IL (Lockhart 2011: 3).

CHELSA advised that core IL skills at foundation level be implemented nationally (De Jager and Nassimbeni 2003, Esterhuizen and Kuhn 2010: 100). Sayed and De Jager (1997: 9) found that a generic, stand-alone course was ineffective in teaching IL skills to students. Instead, IL training skills must be context-specific and embedded into subject knowledge. Previously at CPUT, traditional methods of teaching were used, and it was found that the IL stand-alone method was indeed ineffective. CPUT followed the NQF and CHELSA recommendations. An audit of the faculties' subject guides showed that IL skills were partially integrated into the faculty's curriculum, but were not covered in broad scope, depth, theoretical perspective or approach according to the IL standards. The CIL aimed to ensure that all the standards of IL were incorporated into the curriculum. Compliance would be monitored by the IL Committee. The CIL is a five-module programme, taught over five weeks, with sixty to ninety minutes per module using the lecturers' class time.

\subsection{Collaboration}

Engagement between lecturers and librarians plays a critical role in implementing an IL programme. The literature reviewed will focus on cases of non-collaboration, collaboration, and student improvement and lecturer feedback. Student improvement can be shown by assessment results and lecturers' evidence of improved student performance. Studies show instances of non-collaboration. Lecturers were excluded from the consultative and decision-making processes in IL (McCluskey 2011: 61). If librarians work collaboratively with lecturers, they would discover lecturers' understanding of IL (Mar-Rounds 2011). In addition, Meulemans and Carr (2013: 80) criticised once-off sessions and on-demand instruction required by lecturers as ways to address deficiencies in student skills, or to fill in when lecturers are away. The above scenario describes the way that lecturers collaborated with librarians at CPUT prior to the CIL. Librarians acceded to the lecturers' requests due to concern for the students' lack of IL skills.

For successful collaboration, librarians and lecturers should have a shared vision, mutual understanding of IL goals, and practice team work and continuing communication (Ivey 2003: 102, Chapman and West-Burnham 2010: 132, Wenger in McCluskey 2011: 61). García-Bajo (2009: 51) and Saunders (2012: 231) confirm the importance of shared responsibility between lecturers and librarians, and that $\mathrm{IL}$ should be integrated in all programmes of study. At a COF meeting at CPUT, librarians presented the $\mathrm{ClL}$ to the lecturers. Agreement was reached of the shared vision, responsibility and IL content between the stakeholders. The COF acknowledged the importance of IL as part of the curriculum, but with a few revisions. Thereafter, the CIL was registered as a short course.

\subsection{Student improvement}

There is a correlation between surface level and deep level of learning. Asher (2003: 53) proposed that, when IL is introduced to students at an appropriate level, students understand the work and can apply the IL skills. This could be linked to student performance. If not embedded in a course, IL may become superficial and students do not develop 
sufficient IL skills. Dubicki (2013: 114) asserts that embedding IL into course content enabled lecturers to assess whether IL learning has taken place. This assertion is supported by Hanlan, Ziino and Hoffman's (2013: 1445) research which showed that there was an increase in the quality and diversity of citations as well as in the quantity of sources found in reference lists after an embedded IL intervention. Hegarty and Carbery (2010) reported that the majority of the students rated an embedded IL programme to be practical and useful.

\subsection{Lecturers' feedback}

Lecturers are able to provide evidence that students have learnt new IL skills, therefore their feedback is important for librarians. Lecturers control the learning outcomes of students (Orr and Cribb 2003: 44), therefore they are the best sources of objective feedback (Ivey 2003). Feedback gathered from a meeting with CPUT lecturers endorsed the importance and the value of $\mathrm{IL}$ in the curriculum. This case study embraced the collaborative commitment between lecturer and librarians to fulfil the CIL implementation, improve students' performance and enhance the programme.

\section{Research methodology}

This paper followed a case study research design. Fourie (2012) and Leedy (2010) stated that case studies are in-depth investigations of individuals, groups or situations. The purpose is "to explore causation in order to find underlying principles" (Fourie 2012: 22 citing Babbie \& Mouton 2006 and Thomas 2011). Adelmann (2008: 54 citing Kardos and Smith 1979) wrote that:

The analysis of a case study requires the application of a researcher's knowledge and thinking skills to a real situation. To learn from a case study analysis the researcher will be "analysing, applying knowledge, reasoning and drawing conclusions".

In this way a case study enables researchers to have a thorough understanding of activities within their context (Saunders and Lewis 2012: 116). The case study used mixed research methods. The authors were the main data collectors, were central to the research process and gained first-hand knowledge from the case study. This is referred to as credible "inter subjectivity" (Babbie \& Mouton 2006). Quantitative techniques were used to gather and analyse statistics from four variables: students' attendance, pass rate, failure rate, and absence from the assessments. Data was captured in Excel spreadsheets. The average percentages were calculated for each variable. The results were reported and discussed with lecturers in a focus group session. Qualitative techniques employed interview questions that were prepared by librarians and sent to lecturers to respond to during the focus group session. Ten FoB and five FID lecturers were invited to the focus group, which nine lecturers from the FoB and one lecturer from FID attended. Feedback from lecturers was a key component to the success of the CIL. Librarians presented to the lecturers the findings of the statistics on the attendance, pass rate, failure rate, and assessment. Lecturers provided feedback on their perspectives of the value of the CIL and its impact on the performance of students. Conclusions were drawn, and suggestions were made for the future of the CIL programme at CPUT.

\subsection{Procedure}

The CIL modules were presented at faculty departmental meetings so that lecturers were informed about what the course entails. Both faculties opted for the stand-alone programme to be delivered by librarians during the lecturers' class time. Lecturers were invited to observe the training and could evaluate the impact of the programme on student learning. The FoB IL classes were taught at the libraries' venues whereas the FID classes were taught in the faculty's venues. For all modules, students completed the enrolment form and the attendance register. The attendance register was forwarded to lecturers for academic purposes. The population were departments in the two faculties with the sample size being $71 \%$ for FoB (ten out of fourteen) and $57 \%$ for FID (four out of seven). The sample was representative of the two faculties. Participants were first-year and ECP students from both faculties. Big classes (35-250) were divided into smaller classes of 35-50 students.

\subsection{Information Literacy teaching methods}

Previously, the teaching approach to IL was the traditional class approach. Wang (2007) refers to this approach as placing the teacher as the expert in the class while the students are passive learners. Armellini and Jones (2008) concur with Wang (2007) that teacher-centred learning is concerned with transmission teaching. In the past, the IL sessions at CPUT were on-demand and once-off. Lecturers' involvement in the teaching process was rushed, there were no in-class IL exercises and there was no student involvement in the learning process. Students' comments on training were that it 
was "good but [with] an overload of information". A new teaching approach was needed which would deepen their understanding and application of IL skills in their academic work.

A conscious shift in teaching approach was made by the authors of this paper, namely to a student-centred teaching approach. Armellini and Jones (2008) stated that a student-centred approach encourages active participation and engagement with class content. Armellini and Jones (2008) cite Ramsden (2003) that this approach encourages deep learning. Deep learning enables students to link new concepts to prior knowledge in any environment, becoming more critical learners.

Librarians must not only know the IL standards but be able to facilitate the teaching of them (Wang 2007: 152). Their new role was to facilitate and guide students to engage with the content of the course. Peer-to-peer learning was introduced. This collaborative learning environment created better understanding of the work. It enabled students to learn from each other. It also served to deal with language barriers in diverse student groups.

The class was in the form of a workshop using PowerPoint for presentations, in-class active learning activities and discussions for student engagement. In preparation for the IL training, the librarians requested an assignment from lecturers. In all five modules, class activities and exercises were based on the assignment to illustrate content, discipline value and to capture the students' interest. PowerPoint presentations, class activities and exercises were uploaded onto Blackboard for easy access by students. Librarians did not have a presence on Blackboard but, due to the collaboration with the lecturers, they could load content onto the lecturers' pages. The summative assessment was taken by students on Blackboard.

The learning outcomes of the IL modules focused students' understanding of IL concepts and how to apply information skills learnt to the subject content. Module 1 focused on topic analysis and search strategy. Students needed to engage with their assignment and were required to analyse the assignment, identify keywords and synonyms, and use Boolean operators to create a search strategy. In order to assess whether learning had taken place, students were asked for reasons for their choice of keywords or phrases and the relevance to the assignment. This interaction aimed to build their depth of IL knowledge. This step was significant as Hartmann (2001: 116) says that "knowing which words to use" improves students' understanding of the topic and improves their analytical skills. In contrast, students' inability to understand this important skill is a barrier to retrieve and engage effectively with the sources and content. On a conceptual level, students' thinking was isolated. Their thinking was guided into recognising patterns and interconnectedness between concepts (keywords, synonyms, phrases). Language surfaced as a barrier to understanding certain IL concepts. Peer assistance in group work was employed and this encouraged the translation of IL concepts into the mother tongue of the students, thus aiding the students' understanding of what was being imparted.

In Module 2, students had to apply search strategies from Module 1 and use information tools to retrieve materials from the library's online catalogue and relevant journal articles from the databases. Using the search strategies reinforced what they learnt previously to retrieve content successfully. For Module 3, students had to apply the CRAAP test (currency, relevance, accuracy, authority, purpose) (Blakeslee 2004: 6) to different information sources which tested their understanding of how to evaluate sources. The parts of books and journals and the value of the information found therein were emphasised. Students had to consult these sources to extract relevant information from different parts of the sources. The librarians' observation was that students struggled with this exercise. Students were mainly from a disadvantaged educational background, lacking the skills of using print and online material. Students saw the value of this exercise on how to extract relevant information for their assignments and it generated enthusiastic participation. Being able to differentiate between scholarly and popular journals and the value of each to their assignment guided the students to using quality sources. Modules 4 and 5 covered the legal and ethical aspects of copyright, plagiarism and referencing techniques.

\subsection{Assessment}

Assessment highlighted the relationship between teaching, learning and assessment. According to Lindauer (2004), assessment should examine three areas: the learning environment, the IL program components and student learning outcomes. In the learning environment (teaching), training was with small groups, in workshop mode and was interactive, which encouraged independent learning. The IL program components (learning) used theoretical, practical, blended and self-learning methods. Student learning outcomes (assessment) could be measured by their understanding of content, inclass activities and reflection at regular times.

Each of the modules addressed its own broad learning outcomes with specifically designed learning activities to prepare students to do the assessments. Formative assessments were completed as in-class exercises and these were good indicators of the level of student learning. The summative assessment comprised of 100 randomised multiple-choice questions (MCQs) so no two students had the same set of questions. The MCQs were workshopped with all the librarians 
involved in teaching IL across the different faculties. All questions were based on the five modules. The students' results were available to them immediately after the assessment.

\section{Results}

While continuous assessment was observed throughout the five modules as described above, this study reports on statistics on student attendance, the pass and failure rate, and the summative assessment. Those who were absent from the assessment did not feature in the calculations.

\subsection{Attendance}

Attendance figures were calculated according to the number of attendees across the five modules. The average attendance was calculated. For the ten first-year classes there was a $42 \%$ average attendance across all departments, and for the ECP classes there was a $23.6 \%$ average attendance across all departments. Average FID attendance of three first-year classes was $68 \%$ across all departments.

Table 1 Assessment results

\begin{tabular}{|c|c|c|c|c|c|c|}
\hline \multicolumn{7}{|c|}{ Faculty of Business (FoB) } \\
\hline Subjects & $\begin{array}{l}\text { Class } \\
\text { size }\end{array}$ & $\begin{array}{c}\begin{array}{c}\text { Absent } \\
\text { from }\end{array} \\
\text { assessment } \\
(\%)\end{array}$ & $\begin{array}{c}\text { Wrote } \\
(\%)\end{array}$ & $\begin{array}{c}\text { Pass } \\
(\%)\end{array}$ & $\begin{array}{l}\text { Fail } \\
(\%)\end{array}$ & $\begin{array}{c}\text { Average } \\
\text { attendance }\end{array}$ \\
\hline Accounting 1 & 30 & - & 100 & 87 & 13 & 24 \\
\hline Entrepreneurship 1 & 108 & 22 & 78 & 75 & 25 & 53 \\
\hline Human Resources Management 1 & 151 & 70 & 30 & 78 & 16 & 36 \\
\hline Management 1 & 155 & 35 & 65 & 84 & 16 & 47 \\
\hline Management $1 \mathrm{P} / \mathrm{T}$ & 59 & 51 & 49 & 66 & 34 & 42 \\
\hline Marketing 1 & 129 & 57 & 43 & 88 & 13 & 58 \\
\hline Public Management 1 & 70 & 46 & 54 & 84 & 16 & 47 \\
\hline Retail The FoB Management 1 & 203 & 42 & 58 & 80 & 20 & 71 \\
\hline Retail The FoB Management $1 \mathrm{P} / \mathrm{T}$ & 8 & 50 & 50 & 100 & 0 & 1 \\
\hline Tourism 1 & 81 & 23 & 77 & 89 & 11 & 42 \\
\hline Events Management ECP & 33 & 39 & 61 & 100 & 0 & 31 \\
\hline Human Resources Management ECP & 36 & 44 & 56 & 45 & 55 & 31 \\
\hline Management ECP & 35 & 54 & 46 & 69 & 31 & 20 \\
\hline Office Management and Technology ECP & 33 & 21 & 79 & 69 & 31 & 23 \\
\hline Public Management ECP & 41 & 34 & 66 & 59 & 41 & 19 \\
\hline Tourism ECP & 33 & 18 & 82 & 56 & 44 & 29 \\
\hline Entrepreneurship ECP & 39 & 95 & 5 & 100 & 0 & 11 \\
\hline \multicolumn{7}{|c|}{ Faculty of Informatics and Design (FID) } \\
\hline Subjects & $\begin{array}{l}\text { Class } \\
\text { size }\end{array}$ & $\begin{array}{c}\begin{array}{c}\text { Absent } \\
\text { from }\end{array} \\
\text { assessment } \\
(\%)\end{array}$ & $\begin{array}{c}\text { Wrote } \\
(\%)\end{array}$ & $\begin{array}{c}\text { Pass } \\
(\%)\end{array}$ & $\begin{array}{l}\text { Fail } \\
(\%)\end{array}$ & $\begin{array}{l}\text { Average } \\
\text { attendance }\end{array}$ \\
\hline Fashion 1 & 45 & 7 & 93 & 98 & 2 & 32 \\
\hline Information Technology 1 & 228 & 13 & 87 & 93 & 3 & 150 \\
\hline Multimedia 1 & 40 & 10 & 90 & 94 & 14 & 23 \\
\hline Surface Design 1 & 22 & 100 & 0 & 0 & 0 & 18 \\
\hline
\end{tabular}

\subsection{Pass and failure rates}

The pass rate was calculated according to the number of students who had written the assessment and not according to class size. The class size would have produced a skewed result because of the zero value of those who were absent from the assessment. In the FoB, after seventeen IL classes, first-year students had an $83 \%$ average pass rate across all ten departments; the ECP students had a $71 \%$ average pass rate across seven departments. FID had a $95 \%$ average 
pass rate across three departments. FoB students faced many challenges. The failure rate for the FoB students was $17 \%$ for first-year students and 29\% for ECP students. In comparison, the FID failure rate was 5\%.

\subsection{Absence from the assessment}

In the FoB, $40 \%$ of first-year students across the ten departments did not write the assessment; $44 \%$ of ECP students across seven departments did not write. In the FID, 100\% of Surface Design students did not write the assessment.

\subsection{Assessment}

The assessments were administered differently by the FID and the FoB which had an impact on the results of the students. In the FoB, the assessment was not compulsory and had to be completed in the students' own time. In the FID, the assessment was compulsory and was done during scheduled class time. In total, 974 students wrote the assessment. The FoB recorded 698 and FID, 276 students. In the FoB, $78 \%$ (547 out of 698 students) obtained the IL certificate. In the FID, $93 \%$ (259 out of 276 students) obtained the IL certificate. Table 1 shows the results of the study.

\subsection{Librarians' view of the CIL}

Librarians analysed the lecturers' feedback from the focus group and reconciled it with their own experiences throughout the stages of the CIL programme. The positive responses from lecturers showed that the CIL had merit and that it would be continued but needed to be improved.

The lecturers' responses confirmed the long-held view of librarians that students have an information skills deficiency. By students participating in the $\mathrm{CIL}$ and having been shown how to work with information to achieve better academic results, lecturers and students alike realised the extent of the students' deficiency. The CIL, and by implication the library, thus does make a meaningful contribution to the learning and teaching of students.

Students respond positively to IL training in environments that are conducive to their learning (Detlor et al. 2011). Students were receptive to the new form of training, which was step-by-step IL instruction which made it easy for students to follow. Some of the training was held in the library which created a suitable learning environment. Hands-on training was offered which afforded students opportunities to explore and experiment on their own. The new methods had an empowering effect as students approached research more confidently. The new method suited librarians too. The CIL leads students through an information research process. Librarians observed the initial cognitive and technological difficulties that students encountered. They observed changes in the behaviour of students after training. The students increasingly used the library and approached librarians for information and assistance. Students made conscious efforts to use quality sources and cite accurately. These interactions showed that students were applying IL skills in their work and that IL instruction had a positive influence on student learning. The extent of that learning would be research for a follow-up paper.

The value of the CIL is that it addresses deficiencies in students' information abilities. While the CIL is aimed at a basic level, it provides an effective framework to instil information skills into the minds of students. Its value should also be seen in that it is an intervention that occurs at the beginning of the academic career of students. With practice, IL could be used throughout their academic career, be developed to higher levels and eventually be used in their workplaces, in what can be seen as the application of lifelong skills.

\section{Discussion and recommendations}

Lecturers awarded no credit to the assessment results, so it can be assumed that this was a reason that the course was not considered significant by students. Spershott (2014: 2) concurs with this assumption. Non-credit can be seen as having had a large influence on all four variables. Attendance levels across the five modules fluctuated. The first and last modules were well attended, with a noticeable drop in attendance for the middle modules. Both faculties recorded fairly high average attendances: 60\% in the FoB and 68\% in FID. Munn and Small (2017) cite several studies indicating a low student uptake of non-credit bearing IL courses. Average pass rates for both faculties were high: $82 \%$ for the FoB and 95\% for the FID. In their longitudinal study, Laskin and Zoe (2017: 16) reported that "participation in the IL workshops has a positive effect on the student success measures". The CIL's in-class activities, practical application plus the formative assessments in all the modules had an impact on the pass rate.

The percentage of those absent from the assessment was of major concern. Forty percent $(40 \%)$ of the FoB students did not write the assessment. In FID, one entire class did not write the assessment test, which places this class' average for not writing at $100 \%$. There was qualitative evidence for their absence. Challenges were faced by the FoB students in that the summative assessment had to be written online on Blackboard, and students had to find a venue where a computer was available. Many technical problems were experienced. They were unable to log on to Blackboard due to password failures, browsers were incompatible with the assessment, the network was unstable and often there was no 
internet connectivity. Students had to write the assessment in their own time and without supervision by librarians or lecturers. In addition, the assessment took place very close to mid-term and final examinations. Students skipped classes in favour of more important academic tasks. Considering these challenges, the $82 \%$ average pass rate for the FoB students is a significant statistic.

Despite the challenges, the CIL programme's success must be seen in the light that only one department per faculty was targeted to participate in the project, but the departments which participated were significantly more. Large classes were divided into smaller groups which meant that librarians had to train many groups. The fact that the librarians were able to attend to the unplanned large number of classes successfully bears further testimony to their commitment to ensuring the success of the project. In the case of both faculties, looking at the rate of those who attained the certificate, the CIL programme can be viewed as a success. Recommendations and responses of the lecturers were captured and analysed. Lecturers highlighted the positive impact of the IL programme on student learning. Unexpected advantages emanated from the focus group session. It allowed meaningful discussion, librarians and lecturers were able to ask for clarity and address misunderstandings and concerns immediately. Most importantly, it was a major step to collaboration and improving the $\mathrm{CIL}$ programme. Without the focus group session, meaningful dialogue would not have materialised. The most important recommendations were:

- As part of the library's collaboration with the faculties and departments, it should ensure the full implementation of the CIL into the curricula

- CIL must be credit-bearing and compulsory for all students as lecturers found a lack of IL skills in student assignments

- $\quad$ Evidence of IL integration must be reflected in subject guides and rubrics

- Assessments for the FoB students should be supervised by librarians during lecturer class time

- Librarians and lecturers should continue with focus group sessions to improve IL

\section{Conclusion}

The CIL was developed from existing IL standards, guidelines, frameworks, and specially prepared multiple-choice questions to assess the IL skills of students. The $\mathrm{CIL}$ is an activity-based programme which aims to inculcate understanding and the skilful use of information. The CIL enables students to adopt and adapt to the changing nature of the information environment and become critical consumers and creators of information. To attain this, students would need regular practical application of IL.

The inclusive nature of the $\mathrm{CIL}$ enabled the fostering of successful collaboration. Lecturers were engaged at various fora (COF and departmental meetings) prior to implementation of the CIL. The engagement allowed lecturers significant participation in the implementation process. Literature points to the elements that are needed for successful programme implementation. It is significant to note that the $\mathrm{CIL}$ programme had in place all the elements which were lamented in the literature. Having all the elements in place, it can be deduced that the CIL programme has been successful. IL is guided by the CPUT IL policy. The practical implementation of the policy is the CIL programme.

\section{Acknowledgement}

The authors would like to acknowledge the valuable contribution of their colleagues, Patricia Mothopeng and Thundeza Mafungwa.

\section{References}

Adelmann, H. G. 2008. A framework for decision support, capture and re-use. PhD thesis. Loughborough University. [Online]. https://dspace.lboro.ac.uk/2134/33936 (13 August 2018).

American Library Association (ALA). 2000. Information Literacy Competency Standards for Higher Education. Association of College \& Research Libraries. [Online]. https://alair.ala.org/handle/11213/7668 (13 July 2016).

Anyaoku, E., Ezeani, C. and Osuigwe, N. 2015. Information literacy practices of librarians at university libraries in South East Nigeria. International Journal of Library and Information Science, 7(5): 96-102. [Online]. http://www.academicjournals.org/journal/IJLIS/article-full-text-pdf/1267E4653527 (1 October 2016).

Armellini, A. and Jones, S. 2008. Carpe Diem: seizing each day to foster change in e-learning design. Reflecting Education, 4(1): 17-29.

Asher, C. 2003. Separate but equal: librarians, academics and information literacy. Australian Academic \& Research Libraries, 34(1): 52-55. DOI:10.1080/00048623.2003.10755217.

Association of College and Research Libraries (ACRL). 2016. Framework for Information Literacy for Higher Education. [Online]. http://www.ala.org/acrl/standards/ilframework (29 October 2017).

Babbie, E. and Mouton, J. 2006. The practice of social research. South African edition. Cape Town: Oxford University Press. 
Basili, C. 2011. A framework for analyzing and comparing information literacy policies in European countries. Library Trends, 60(2): 395-418.

Blakeslee, S. 2004. The CRAAP Test. LOEX Quarterly, 31(3): 6-7. [Online]. http://commons.emich.edu/loexquarterly/vol31/iss3/4 (22 June 2016).

Calderón-Rehecho, A., Domínguez-Aroca, M-I. and González-Fernández-Villavicencio, N. 2013. State of the art: information literacy in Spanish University Libraries. In Worldwide commonalities and challenges in information literacy research and practice. S. Kurbanoğlu, E. Grassian, D. Mizrachi, R. Catts \& S. Spiranec, Eds. Istanbul: ECIL. 288294.

Cape Peninsula University of Technology (CPUT). 2006. The Vision, mission and strategic plan of the Cape Peninsula University of Technology. Cape Town: CPUT.

Cape Peninsula University of Technology (CPUT). 2009. Information literacy policy. (Unpublished).

Chapman, L. and West-Burnham, J. 2010. Education for social justice: achieving wellbeing for all. London: Continuum.

De Jager, K. and Nassimbeni, N. 2003. An exploration of the current status of information literacy tuition in South African tertiary institutions and proposals for curriculum design. South African Journal of Libraries and Information Science, 69(2): 108-114.

Department of Higher Education and Training (DHET). 2012. Ministerial statement on university funding 2013/2014 and 2014/2015. Pretoria, South Africa: DHET. [Online].

http://www.dhet.gov.za/Financialand\%20Physical\%20Planning/Ministerial\%20Statement\%20on\%20University\%20Fu nding\%20-\%2020132014\%20and\%2020142015\%20,\%20November\%202012.docx (3 May 2017).

Detlor, B., Julien, H., Wilson, R., Serenko, A. and Lavallee, M. 2011. Learning outcomes of information literacy instruction at business schools. Journal of the American Society for Information Science and Technology, 62(3): 572-585.

Dubicki, E. 2013. Faculty perceptions of students' information literacy skills competencies. Journal of Information Literacy, 7(2): 97-125. DOI:10.11645/7.2.1852.

Esterhuizen, E. and Kuhn, R. 2010. CHELSA draft guidelines on information literacy: paving the way to a South African national framework? Innovation: Journal of Appropriate Librarianship and Information Work in Southern Africa, 41(1): 83-106.

Fourie, S. 2012. An evaluation of the effect of coaching on the empowerment of middle managers in the retail sector: a lifelong learning perspective. PhD thesis. University of Stellenbosch.

García-Bajo, M. 2009. Liaison between librarians and lecturers regarding information literacy: a case study of some academic libraries ESE. Estudios Sobre Educación, 17: 45-61. [Online]. http://hdl.handle.net/10171/9842 (2 September 2016).

Hanlan, L., Ziino, R. and Hoffman, A. 2013. Assessing student information literacy skills and the effectiveness of an evolving faculty-librarian collaboration in a first-year design course. Frontiers in Education Conference. 23-26 October 2013. Oklahoma City, USA: IEEE. 1444-1446. DOI:10.1109/FIE.2013.6685070.

Hartmann, E. 2001. Understandings of information literacy: the perceptions of first year undergraduate students at the University of Ballarat. Australian Academic \& Research Libraries, 32(2): 110-122. DOI:10.1080/00048623.2001.10755150.

Hegarty, N. and Carbery, A. 2010. Piloting a dedicated information literacy programme for nursing students at Waterford Institute of Technology Libraries. Library Review, 59(8): 606-614. DOI:10.1108/00242531011073137.

Hernández-Rabanal, C. 2014. The benefits of integrating information literacy activities into the higher education curriculum of future healthcare professionals. In Information literacy, lifelong learning and digital citizenship in the 21st Century. S. Kurbanoğlu, S. Špiranec, E. Grassian, D. Mizrachi \& R. Catts, Eds. Cham: Springer.

International Association of Technological University Libraries (IATUL). 2015. Information literacy policies and standards at IATUL member libraries. [Online]. https://mediatum.ub.tum.de/node?id=1286822 (1 June 2016).

International Federation of Library Associations and Institutions (IFLA). 2015. About the information literacy section. [Online]. http://www.ifla.org/about-information-literacy (1 June 2016).

Idiodi, E. 2005. Approaches to information literacy acquisition in Nigeria. Library Review, 54(4): 223-230. DOI:10.1108/00242530510593416.

Ivey, R. 2003. Information literacy: how do librarians and academics work in partnership to deliver effective learning programmes? Australian Academic \& Research Libraries, 34(2): 100-113. DOI:10.1080/00048623.2003.10755225.

Jarson, J. 2010. Information literacy and higher education: a toolkit for curricular integration. College \& Research Libraries News, 71(10): 534-538.

Laskin, M. and Zoe, L. 2017. Information literacy and institutional effectiveness: a longitudinal analysis of performance indicators of student success. CUNY Academic Works. [Online]. http://academicworks.cuny.edu/ho_pubs/60 (30 October 2017).

Leedy, P. 2010. Practical research: planning and design. $9^{\text {th }}$ ed. Upper Saddle River, N.J. Harlow: Pearson Education.

Li, L., Leung, S. and Tam, G. 2007. Promoting information literacy skills through web-based instruction: the Chinese University of Hong Kong library experience. Library Management, 28(8-9): 531-539.

DOI:10.1108/01435120710837819.

Lindauer, B. 2004. The three arenas of information literacy assessment. Reference \& User Services Quarterly, 44(2): 122-129. 
Lockhart, J. 2015. Increasing library value for users by registering a short course in information literacy. Proceedings of the IATUL Conferences. 5 - 9 July 2015. German National Library of Science and Technology, Hanover, Germany: Purdue. Paper 7. [Online]. http://docs.lib.purdue.edu/iatul/2011/papers/29 (30 June 2016).

Maitaouthong, T., Tuamsuk, K. and Yupin, T. 2012. The roles of university libraries in supporting the integration of information literacy in the course instruction. Malaysian Journal of Library \& Information Science, 17(1): 51-64.

Mar-Rounds, G. 2011. Better understanding teaching faculty's beliefs and behavior towards information literacy: the University of South Pacific perspective. IFLA Final Report: The Researcher-Librarian Partnership. [Online]. http://www.ifla.org/files/assets/library-theory-and-research/Projects/researcher-librarian-report-mar-rounds.pdf (1 June 2016).

McCluskey, C. 2011. Creating information literacy partnerships in higher education. Library and Information Research, 35(1): 59-72.

Meulemans, Y. and Carr, A. 2013. Not at your service: building genuine faculty-librarian partnerships. Reference Services Review, 41(1): 80-90. DOl:10.1108/00907321311300893.

Mugwisi, T. 2015. Role of librarians in teaching information literacy in Zimbabwean and South African universities: a comparative study. Mousaion, 33(1): 23-42.

Munn, J. and Small, J. 2017. What is the best way to develop information literacy and academic skills of first year health science students? A systematic review. Evidence Based Library and Information Practice, 12(3): 56-94. [Online]. https://journals.library.ualberta.ca/eblip/index.php/EBLIP/article/view/28541/21413 (12 November 2017).

Newton Gresham Library. 2010. Information literacy tutorial. Houston, Texas: Newton Gresham Library. [Online]. http://library.shsu.edu/research/guides/tutorials/index.html (3 May 2017).

Orr, D. and Cribb, J. 2003. Information literacy - is it worth the investment? Australian Academic and Research Libraries, 34(1): 42-51. DOI:10.1080/00048623.2003.10755216.

Saunders, L. 2012. Faculty perspectives on information literacy as a student learning outcome. Journal of Academic Librarianship, 38(4): 226-236.

Saunders, M. and Lewis, P. 2012. Doing research in business and management: an essential guide to planning your project. Harlow, London: Pearson.

Sayed, Y. and De Jager, K. 1997. Towards an investigation of information literacy in South African students. South African Journal of Libraries and Information Science, 65(1): 5-12.

Spershott, C. 2014. The design of an online classroom and implementation of an activity. [Online]. er.dut.ac.za/handle/123456789/106 (29 October 2017).

Tshwane University of Technology. 2016. Library information literacy training. [Online]. http://lib.tut.ac.za/library/infolit/infolit-modules.html (1 May 2017).

Virkus, S. 2012. Information literacy from the policy and strategy perspective. Nordic Journal of Information Literacy in Higher Education, 4(1): 16-37.

Wang, L. 2007. Sociocultural learning theories and information literacy teaching activities in higher education. Reference \& User Services Quarterly, 47(2): 149-158. 